\title{
Partial androgen insensitivity syndrome in a 68-year-old patient
}

\author{
Tezcan Sezgin ${ }^{1)}$, Muhammet İrfan Dönmez²), Aylin Dirican ${ }^{3)}$, İsa Deniz ${ }^{4)}$ and Bülent Savut ${ }^{5)}$ \\ ${ }^{1)}$ Konya Training and Research Hospital, Urology, Konya, Turkey \\ 2) Konya Training and Research Hospital, Pediatric Urology, Konya, Turkey \\ 3) Konya Training and Research Hospital, Obstetrics and Gynecology, Konya, Turkey \\ 4) Konya Training and Research Hospital, Radiology, Konya, Turkey \\ 5) Konya Training and Research Hospital, Endocrinology, Konya, Turkey
}

\begin{abstract}
Partial androgen insensitivity syndrome (PAIS) is a form of disorders of sexual development. Besides the issues of gender assignment, the fate of gonads in these patients poses a challenging problem. Debate still remains on the need and/or timing of gonadectomy in either complete or partial androgen insensitivity syndromes. In this case report, we present a 68year-old patient who was raised as a woman, stayed married for 45 years and admitted to our endocrinology department with complaint of male type hair distribution after initial examination following move to a nursing home. Physical examination revealed no breast development, a phallus of $6 \mathrm{~cm}$, labia majoras that include testes and a blind ending vagina. Chromosomal analysis confirmed 46,XY with intact SRY and AZF regions. Pelvic ultrasonography and magnetic resonance imaging results indicated testicular tissue in labia majoras in addition to a rudimentary prostate. Gonadectomy was not offered to the patient due to lacking evidence of benefit in this age group and considering possible hormonal side effects. Our patient might be the oldest patient to be diagnosed with PAIS. Treatment and follow-up protocols for adults with PAIS are not standardized and therefore these patients should be individually evaluated and treated. Risks and benefits of surgery should be kept in mind when suggesting gonadectomy.
\end{abstract}

Key words: Partial androgen insensitivity syndrome, Gonadectomy, Long-term

PARTIAL ANDROGEN INSENSITIVITY SYNDROME

(PAIS) is a form of disorders of sexual development. It is caused by missense mutations in the androgen receptor (AR) gene [1]. These mutations result in a variety of hypomasculine male external genitalia that may be misinterpreted as female and complete male internal genitalia. Gender differentiation might be difficult in early childhood, thus it is often clarified in adolescence with the aid of hormonal and genetic investigations.

Besides the issues of gender assignment, the fate of gonads in these patients poses a challenging problem. There has been growing evidence that indicates increased risk of benign and malignant tumors of the gonads in androgen insensitivity syndrome patients [2]. However, current approach in PAIS is to consider gonadectomy after puberty in order to include the patient for shared decision [3]. We present a case report that

Submitted Jan. 8, 2019; Accepted Mar. 4, 2019 as EJ18-0578 Released online in J-STAGE as advance publication Mar. 28, 2019 Correspondence to: Muhammet İrfan Dönmez, MD, FEBU, Konya Training and Research Hospital, Pediatric Urology, Hacışaban Mah. Yeni Meram Caddesi No: 97 Meram, Konya, 42090, Turkey. E-mail: m_irfan83@yahoo.com includes a patient diagnosed as PAIS at the age of 68 after staying married for 45 years.

\section{Case Report}

A 68-year-old patient who has recently moved into a nursery home was referred to our endocrinology clinic due to male type hair distribution after the initial checkup provided by the institution. History of the patient revealed that the patient has lived in a rural area with very limited access to healthcare facilities almost entire life. The patient has stayed married for 45 years and the husband has died 4 years ago. As a matter of fact, the patient did not have a child. A short while ago before admission, patient has been accepted for a government nursing home and has been staying there. Since the institution provides check-up for the residents, doctor of the institution identified the case during initial visit and referred the patient to our hospital. Patient had no history for previous surgeries and no family member had been diagnosed with disorders of sexual differentiation.

Physical examination of the patient showed no breast development, male type hair distribution both in the 
facial hair and the chest. Genital examination revealed a hypospadiatic phallus of $6 \mathrm{~cm}$, labia majoras that included testes and a blind ending vagina of $3 \mathrm{~cm}$. Hormonal analysis results were as follows; FSH: $76.1 \mathrm{IU} / \mathrm{L}, \mathrm{LH}$ : $28.2 \mathrm{IU} / \mathrm{L}$, Estradiol: $56.4 \mathrm{pg} / \mathrm{mL}$ and total testosterone: $388.9 \mathrm{ng} / \mathrm{dL}$. Serum creatinine level was $0.75 \mathrm{mg} / \mathrm{dL}$ and electrolytes were all within normal range. The patient was $155 \mathrm{~cm}$ in height and $53 \mathrm{~kg}$ in weight indicating a BMI score $22.06 \mathrm{~kg} / \mathrm{m}^{2}$. Systolic blood pressures were within a range of $120-135 \mathrm{mmHg}$ whereas diastolic pressures were between $75-85 \mathrm{mmHg}$ on several measurements. The patient's $\mathrm{Hb}$ level was $14.5 \mathrm{~g} / \mathrm{dL}$ whereas WBC count was $7,500 / \mathrm{mm}^{3}$ and platelet count was $320,000 / \mathrm{mm}^{3}$, respectively. Total cholesterol level was $161 \mathrm{mg} / \mathrm{dL}$, HDL level was $47 \mathrm{mg} / \mathrm{dL}$, LDL level was $84 \mathrm{mg} / \mathrm{dL}$ and triglyceride level was $149 \mathrm{mg} / \mathrm{dL}$. Coagulation parameters were also normal (INR: 0.9, aPTT: $21.2 \mathrm{~s}$ and PT: $8 \mathrm{~s}$ ). Liver function tests were within normal range (ALT: $9 \mathrm{U} / \mathrm{L}$, AST $14 \mathrm{U} / \mathrm{L}$ ). Also, ALP level was $96 \mathrm{U} / \mathrm{L}$ and $\mathrm{LDH}$ level was $84 \mathrm{U} / \mathrm{L}$.

Additionally, HbA1C level was 5.8\%. Testicular tumor markers were also normal (BHCG: $<2.0 \mathrm{IU} / \mathrm{L}$ and aFP: $2.6 \mu \mathrm{g} / \mathrm{L})$. Serum total PSA level was $0.07 \mu \mathrm{g} / \mathrm{L}$.

Ultrasonography of the labia majora showed bilateral testes with no signs of evident solid mass. However, left sided varicocele was found (veins of pampiniform plexus reaching to a diameter of $2 \mathrm{~mm}$ that was refluxing via valsalva). Magnetic resonance imaging of pelvis revealed presence of prostate $(32 \times 30 \times 28 \mathrm{~mm})$ as well as seminal vesicles. Also, bilateral testicular tissues (Right $-22 \times 14 \times 18 \mathrm{~mm}$, Left $-24 \times 16 \times 19 \mathrm{~mm})$ were observed in the inguinal canals/labia majora (Fig. 1). No evidence of neoplasia of the testes or adjacent structures such as epididymis was reported. There were no signs of ovaries or Müllerien structures such as fallopian tubes, uterus or upper part of vagina. After injection of gadolinium, there was no pathologic enhancement. DEXA was also requested for the patient that resulted a $T$ score of 2.5 and a $\mathrm{Z}$ score of 4.5 ( $\mathrm{L}_{1-5}$ levels). Chromosomal analysis revealed 46,XY with intact SRY and AZF regions (Fig. 2). However, due to technical problems, sequence of AR gene could not be evaluated. Additionally, depression was diagnosed after psychological evaluation.

Gonadectomy was not offered and patient was asked to attend follow-up visits and psychological support.

\section{Discussion}

Patients with PAIS may have a variety of external genitalia that may result in late identification of those individuals [4]. In combination with lack of access to healthcare, tragic incidents may happen as in our case that these individuals may go undiagnosed for decades. It

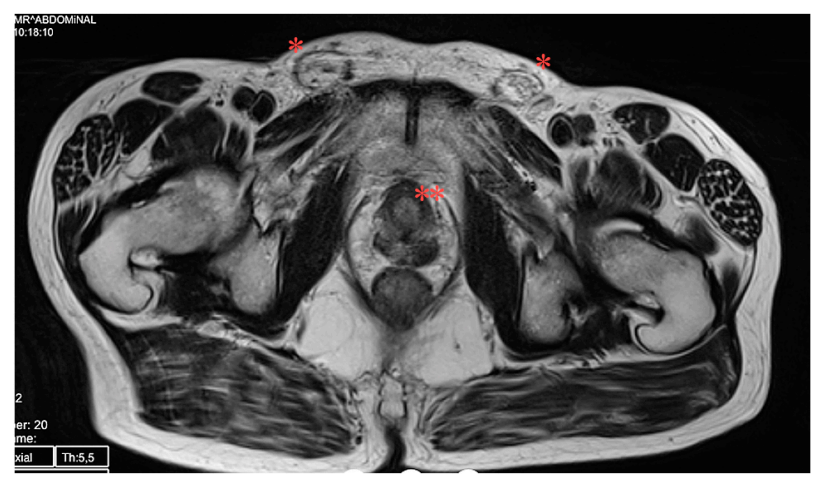

Fig. 1 Magnetic resonance imaging of the pelvis. (*: testes, **: prostate)

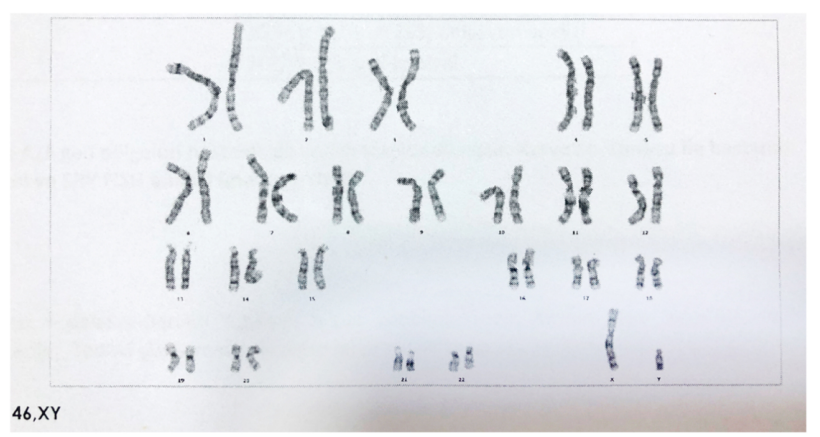

Fig. 2 Chromosomal analysis representing 46,XY.

should also be kept in mind that late diagnosis may carry a huge psychological burden for the patient and proper psychological support should be maintained. During initial evaluation, psychiatric assessment of our patient revealed depression. Proper medical treatment was initiated after diagnosis and patient was asked to attend control psychological visits.

One of the main problems in androgen insensitivity syndrome patients is the necessity/timing of gonadectomy. Previously, these patients had been undergoing prophylactic gonadectomy however recent data showed that may be unnecessary $[5,6]$. The rationale behind gonadectomy is the risk of germ cell tumors in these patients. In a cohort concerning PAIS patients, $16.7 \%$ have been diagnosed with gonadoblastoma [7].

However, data on older patients are scarce. Of note, higher rates of surgical morbidity comes along with increased age. Older studies about patients with undescended testis indicate an age cut-off of 50 years for post-pubertal orchiectomy [8]. In addition, a recent study about risk of post-pubertal orchiectomies for undescended testes has found that prophylactic orchiectomy should be done in males under 50 years if their ASA score is 1 , while those with ASA score 2 should undergo surgery only if they are younger than 35 years of age [9]. In a 
very comprehensive study by Cools et al., the authors have stated that the data regarding older patients were not clear, and have concluded malignant transformation in androgen insensitivity is a rare event. Therefore, they consider gonadectomy should be a shared decision with the patient and the medical team [3]. In accordance with aforementioned data, we did not offer surgical removal of the gonads in our case.

It is also debatable if follow-up of these patients is warranted and up to what age. Annual ultrasonography of the testes has been investigated [10]. However, it should be remembered that specificity of US is not optimal. MRI has been shown to be superior but it is not cost-effective for surveillance [11]. Also, classical tumor markers of testicular germ cell tumors, aFP and BHCG are of limited use due to their rare expression in seminomas that encounter the main portion of germ cell tumors in androgen insensitivity syndromes [12].

Moreover, in the absence of gonadectomy (or under protective effects of testosterone), patients might be protected from cardiovascular diseases, glucose intolerance, and osteoporosis. In terms of osteoporosis, $\mathrm{T}$ and $\mathrm{Z}$ scores of the patient in DEXA were remarkably good.

Our case report identifies a newly diagnosed PAIS patient in $7^{\text {th }}$ decade of life. No signs of gonadal tumors were detected during the evaluation. Consequently, we believe that not every patient would benefit from surgery and gonadectomy should be tailored.

\section{Conclusion}

Treatment and follow-up protocols for adults with PAIS are not standardized and therefore these patients should be individually evaluated and treated. Risks and benefits of surgery should be kept in mind when suggesting gonadectomy.

\section{Acknowledgements}

None.

\section{Conflict of Interest}

None of the authors have any potential conflicts of interest associated with this research.

\section{Funding}

None.

\section{References}

1. Hughes IA, Davies JD, Bunch TI, Pasterski V, Mastroyannopoulou K, et al. (2012) Androgen insensitivity syndrome. Lancet 380: 1419-1428.

2. Tack LJW, Maris E, Looijenga LHJ, Hannema SE, Audi L, et al. (2018) Management of gonads in adults with androgen insensitivity: an international survey. Horm Res Paediatr 90: 236-246.

3. Cools M, Wolffenbuttel KP, Hersmus R, Mendonca BB, Kaprova J, et al. (2017) Malignant testicular germ cell tumors in postpubertal individuals with androgen insensitivity: prevalence, pathology and relevance of single nucleotide polymorphism-based susceptibility profiling. Hum Reprod 32: 2561-2573.

4. Mongan NP, Tadokoro-Cuccaro R, Bunch T, Hughes IA (2015) Androgen insensitivity syndrome. Best Pract Res Clin Endocrinol Metab 29: 569-580.

5. Dohnert U, Wunsch L, Hiort O (2017) Gonadectomy in complete androgen insensitivity syndrome: why and when? Sex Dev 11: 171-174.

6. Abaci A, Catli G, Berberoglu M (2015) Gonadal malignancy risk and prophylactic gonadectomy in disorders of sexual development. J Pediatr Endocrinol Metab 28:
$1019-1027$.

7. Liu AX, Shi HY, Cai ZJ, Liu A, Zhang D, et al. (2014) Increased risk of gonadal malignancy and prophylactic gonadectomy: a study of 102 phenotypic female patients with Y chromosome or Y-derived sequences. Hum Reprod 29: 1413-1419.

8. Martin DC, Menck HR (1975) The undescended testis: management after puberty. J Urol 114: 77-79.

9. Shah A, Feustel PJ, Knuth J, Welliver C (2018) An updated mortality risk analysis of the post-pubertal undescended testis. Can Urol Assoc J 13: E1-E6.

10. Hoei-Hansen CE (2008) Application of stem cell markers in search for neoplastic germ cells in dysgenetic gonads, extragonadal tumours, and in semen of infertile men. Cancer Treat Rev 34: 348-367.

11. Kim W, Rosen MA, Langer JE, Banner MP, Siegelman ES, et al. (2007) US MR imaging correlation in pathologic conditions of the scrotum. Radiographics 27: 1239-1253.

12. Cools M, Looijenga L (2017) Update on the pathophysiology and risk factors for the development of malignant testicular germ cell tumors in complete androgen insensitivity syndrome. Sex Dev 11: 175-181. 